\title{
Carcass Characteristics of Brahman Crossbred Cattle in Indonesian Feedlot
}

\author{
Kuswati $^{1)}$, Kusmartono ${ }^{2)}$, T.Susilawati ${ }^{2)}$, D. Rosyidi ${ }^{2)}$ A. Agus ${ }^{3)}$ \\ ${ }^{I}$ Postgraduate Program, Faculty of Animal Husbandry, University of Brawijaya. Jl. Veteran, Malang 65145. \\ Indonesia \\ ${ }^{2}$ Faculty of Animal Husbandry, University of Brawijaya. Jl. Veteran, Malang 65145. Indonesia \\ ${ }^{3}$ Faculty of Animal Husbandry, University of Gadjah Mada. Jl. Fauna, Jogyakarta. Indonesia
}

\begin{abstract}
Carcass traits are important measures in beef cattle production, expressing economic efficiency and meat quality. For those reasons, carcass traits of Brahman crossbred cattle in Indonesian feedlot of different fattening period were assessed. Thirty-three Brahman crossbred steers and thirty-three Brahman crossbred heifers with initial body weight of $399-463 \mathrm{~kg}$ were fed same diet and reared for fattening in different period as treatment, i.e. 1 month, 2 months and 2.5 months for slaughter. The diet contained: dry matter 84.7\%, crude protein 12,2\%, and GE 3,709 kcal/kg DM. At the end of each fattening period, 11 steers and 11 heifers were weighed, rested for 12 hours and then slaughtered in commercial local abattoir in West Java for carcass evaluation, including weight of carcass (dressing percentage), its composition (bone, meat and fat percentage, meat bone ratio), and meat quality (marbling fat, meat and fat color). Carcass was divided into two same parts by longitudinally cutting from cranial to dorsal part. A part of the carcass was separated for its component (bone, meat, and fat), then, each component was weighed. Cutting of carcass sample was taken between the $12^{\text {th }}-13^{\text {th }}$ ribs for marbling, meat and fat color observation. The data were subjected to analysis of variance of Nested Randomized Block Design and Least Square Differences using exell programe. The results showed that sex had no effect on carcass charateristics except that bone weight was higher in the steers. Based on days on feed the highest percentage of carcass in steer and heifer were reached after 2.5 months of day on feed $(56.60 \%$ and56.3\%). Meat percentage in the steers and heifers afterl month and 2 months were the same (75\%). Similar values were found in the percentage of bone in the steers and heifers after 2 months fattening periods (14.4 and $14.8 \%$, respectively). However, the percentage of fat in heifers was higher (9.3\%) than in the steers (8.2\%) after 2.5 months fattening periods. From these results it can be concluded that the percentage of bone varied, while the percentage of meat and fat increased as days on feed increased.
\end{abstract}

Key Words: beef, sex diffrences, steers, heifers, beef yield

\section{Introduction}

Crossbred Brahman fattened in feedlots in Indonesia come from Australia. The crossbred Brahman cattle show the superior carcasses compared to the indogenous local cattle (Smith et al., 2007).The weight and the proportion of different tissue (fat, muscle and bone) in the carcass and carcass tissue distribution have significant economic value (Lambe et al., 2010). The value of carcass is determined by 3 factors: 1) weight, 2) evaluation of intramuscular fat and 3) physiological maturity (Lawrence et at., 2008).

Some carcass characteristics have been widely studied by Behrends et al., (2009) who stated that the performance during the weaning determines the performance of steers in feedlot, carcass characteristic meat and tenderness. Therefore, an evaluation on carcass characteristics of crossbred Brahman as effects of sex and fattening period is needed for management improvement. The differences in growth patterns between cattle of different breeds will lead to differences in the composition of carcasses, meat quality, especially intramuscular fat (Chambaz et al., 2002; Cuvelier et al., 2006).

Carcass percentage is very important trait in the feedlot and is influenced by age, sex, castration, carcass weight, meat yield, meat and carcass quality (McKlerrnan, 2007). A medium crossbred Brahman has been reported able to produce carcass of 52-58\% of live weight (Hafid, 2004).

There are some ddifferences in carcass composition, cut ability, economic value of carcass and distribution of certain muscle groups between bull and steers. Bulls have higher percentage of meat, percentage of the hind legs and waist than steers, while the bone percentage is similarr. Masculinity influences the distribution of chuck, neck, brisket and hind shin cuts, and gives a significant effect on the percentage of hind shin and thin flank (Pietersen et al., 1998). Sex ddifferentces lead to differences in adult sizes. Between bull, steers or young bulls and heifers, bull has a lowest percentage of carcass because it has a larger head, heavy shoulder and greater proportion of hindquarter than the steers and heifers.

The main components of carcass consist of bone, meat and fat, and the carcass quality is influenced by balance of these three components. The carcass composition is evaluated through these three main tissues. It 
was reported that decreasing the percentage of bone and muscle resulted in increased in fat percentage (Aberle et al., 2001). Changes in the proportions of bone, muscle and fat are parallel with the order of growth: first bone, then muscle and last fat. Hafid. (2004) reported that there were differences between steer and heifer their bone component, in which heifer bone components was significantly lighter than those of steer.

According to Drake (2010) the three most influential factors towards the quality of the carcass is the number of feeding days (days on feed), body weight and age and these three factors are likely to have a good interaction. The increase in the number of days on feed will increase the marbling (the quality grade), the value of yield grade and carcass weight. Moreover, it can also increase the size of the carcass and external fat cover.

In the tropical conditions, there are many factors that influence the production of carcass. Therefore it is necessary to evaluate the production of crossbred Brahman carcasses and how to improve the quality of beef in Indonesia. This study aimed to evaluate the carcass characteristics of crossbred Brahman in the steers and heifers after 1 month, 2 months and 2.5 months in the feedlot following a 1-month adaptation period.

\section{Materials And Methods}

Crossbred Brahman steers and heifers (each of 30 heads), with initial body weight of $399-463 \mathrm{~kg}$ were fed same diet and reared for fattening in different period as treatment, i.e. 1 month, 2 months and 2.5 months. The diet was composed of cassava chips, cassava waste or pulp, corn bran, wheat pollard, molasses, coffee pulp, copra meal, oil palm meal, soybean meal, mineral, sodium bicarbonate, urea, starbio, and CPO. The diet contained $84.7 \%$ dry matter, $12.2 \%$ crude protein, and $3.709 \mathrm{kcal} / \mathrm{kg}$ DM gross energy.

At the end of each fattening period, 11 steers and 11 heifers were weighed and then slaughtered at commercial local abattoir in West Java for carcass evaluation. Carcass was obtained by cutting the head, the front legs, and the hind legs at a site between os occipitale and os atlas, between between carpus and metacarpus, and between tarsus and metatarsus, respectively, two oxtails were joined together into carcass (INS, 2008).

The carcass was evaluated for its hot carcass weight (HCW), dressing percentage, carcass composition (bone, meat and fat percentage, meat: bone ratio) and meat quality (marbling fat, meat and fat color).

The carcass was longitudinally split into two same parts using Kent Masters's chainsaw along the spine and sternum. The carcass was cleaned by spraying some clean water. Each part was separately weighed using a digital scale and then summed together for both parts to determine total carcass weight. A part of the carcass was separated using a victorinox boning knife for its meat, bone, and fat. The three components were separately weighed as the carcass components. The loin part was taken as a sample as much as $0.5 \mathrm{~kg}$ from the longissimus dorsi muscle in between $12^{\text {th }}$ and $13^{\text {th }}$ ribs, then packed and chilled until the inner temperature reaching $0^{\circ}-7^{\circ} \mathrm{C}$ for observation of meat and fat color (score $1=$ very poor to $9=$ very good) and marbling fat (score $1=$ very poor to 12 = very good) according to the procedure of ISN 2008 for Brahman crossbred in Indonesian feedlot.

The data were subjected to analysis of variance of Nested Randomized Block Design and Least Square Differences using Exell program.

\subsection{Carcass Weight}

\section{Results And Discussion}

Initial weight, weight gain, slaughter weight, hot carcass weight, and dressing percentage are important indicators in evaluating feedlot or beef cattle fattening. Those indicators for crossbred Brahman steers and heifers as affected by different period of fattening in this experiment are presented in Table 1 .

Table 1. Daily weight gain, slaughter weight, carcass weight, and dressing percentage of Brahman crossbred steers and heifers as affected by different period of fattening

\begin{tabular}{|c|c|c|c|c|c|}
\hline \multirow{3}{*}{$\begin{array}{c}\text { Weight parameters } \\
\text { Initial body weight }(\mathrm{kg})\end{array}$} & \multirow{3}{*}{$\begin{array}{c}\text { Sex } \\
\text { Steer }\end{array}$} & \multicolumn{3}{|c|}{ Period of fattening (month) } & \multirow{2}{*}{ Average } \\
\hline & & 1.0 & 2.0 & 2.5 & \\
\hline & & $384.7 \pm 14.2$ & $385.2 \pm 16.5$ & $386.6 \pm 25.4$ & $385.5 \pm 18.7^{q}$ \\
\hline & Heifer & $366.8 \pm 22.8$ & $369.8 \pm 10.3$ & $371.0 \pm 7.8$ & $369.2 \pm 14.8^{p}$ \\
\hline \multirow[t]{2}{*}{ Daily weight gain (kg) } & Steer & $1.2 \pm 0.2^{\mathbf{b}}$ & $0.9 \pm 0.3^{\mathrm{a}}$ & $0.8 \pm 0.3^{\mathrm{a}}$ & $1.0 \pm 0.3$ \\
\hline & Heifer & $1.0 \pm$ & $1.1 \pm$ & $1.0 \pm 0.2$ & $1.0 \pm 0.2$ \\
\hline \multirow[t]{2}{*}{ Slaughter weight (kg) } & Steer & $422.0 \pm 17.3$ & $438.5 \pm 27.8$ & $450.2 \pm 43.3$ & $436.9 \pm 32.5^{q}$ \\
\hline & Heifer & $396.2 \pm 27.6^{a}$ & $433.5 \pm 16.5^{b}$ & $448.2 \pm 20.2^{\mathbf{b}}$ & $426.0 \pm 30.7^{p}$ \\
\hline \multirow[t]{2}{*}{ Hot carcass weight $(\mathrm{kg})$} & Steer & $221.0 \pm 10.1^{\mathrm{a}}$ & $230.6 \pm 13.8^{a}$ & $254.9 \pm 26.3^{\mathbf{b}}$ & $235.5 \pm 22.7^{q}$ \\
\hline & Heifer & $205.9 \pm 16.6^{\mathrm{a}}$ & $224.4 \pm 20.1^{\mathrm{a}}$ & $253.3 \pm 12.1^{\mathbf{b}}$ & $227.8 \pm 25.5^{p}$ \\
\hline \multirow[t]{2}{*}{ Dressing percentage $(\%)$} & Steer & $52,7 \pm 2,7$ & $52,9 \pm 1,8$ & $56,6 \pm 1,4$ b & $54.1 \pm 2.6$ \\
\hline & Heifer & $51,9 \pm 1,5 \quad$ a & $51,7 \pm 3,8$ & $56,3 \pm 1,4 \quad$ b & $53.3 \pm 3.2$ \\
\hline
\end{tabular}


a,b) Values on the same row under the period of fattening column with different superscript are significantly different $(\mathrm{P}<0.05)$

${ }^{\mathrm{p}, \mathrm{q}}$ ) Values of each parameter under the average column with different superscript are significantly different $(\mathrm{P}<0.05)$

Data in Table 1 showed that steers had significantly higher; slaughter weight, hot carcass weight, and slightly higher dressing percentage than heifers, but both steers and heifers had same daily weight gain. Choat et al (2006) and Reinhardt et al. (2009) reported that carcass quality and marbling score were similar for steers as compared with either intact or spayed heifers. Thus, the difference of slaughter weight as well as hot carcass weight of steers and heifers in this experiment was most likely affected by initial weight. In addition, hot carcass weight is also affected by non-carcass weight including head, both hind and front legs, skin, and visceral, which are less economically important than the carcass. Hence, dressing percentage which is percentage of carcass towards slaughter weight or as calculated as carcass weight over slaughter weight multiplied by 100 is as economically important in carcass evaluation. Dressing percentage of crossbred Brahman steers and heifers in this experiment was $53.3 \%$ and $54.1 \%$, respectively (Table 1 ). These values are in the range of dressing percentage of cattle reported by Mclntyre (2004), which was 45\% and 60\%, 56.9\% for Braford cattle (Orellana et al., 2009) and 52.6\% for Bos indicus (Nellore cattle) (Maggioni et al.,2010). Variation may occur as a result of the varying degree of thoroughness in the cleaning process of carcass (Maggioni et al., 2010).

The length of fattening period with better quality feed affected significantly $(\mathrm{P}<0.01)$ daily weight gain, slaughter weight, hot carcass weight, and dressing percentage. Steers and heifers reared for longer fattening period showed significantly higher slaughter weight, hot carcass weight, and dressing percentage, but lower daily weight gain. Higher slaughter weight and hot carcass weight as a result of longer fattening period were mostly due to the accumulation of weight, since average daily weight gain especially for steers tended to decrease with longer fattening period. However based on data of dressing percentage, it was interesting to note that fattening period of 2.5 months resulted in significantly higher dressing percentage $(56.6 \%$ and $56.3 \%$ for steers and heifers, respectively) than the shorter fattening period 1.0 or 1.5 months $(\mathrm{P}<0.05)$. The decreased in average daily weight gain especially for steers with longer fattening period showed that there was a compensatory weight gain that was high in the beginning due to better feeding in this experiment. The same conditions were also reported by Mandell et al (1998) and Sami et al (1998) who evaluated feeding intensity (extensive and intensive systems) and time on feed (100 and 138 days) on performance, carcass characteristics and meat quality of Simmental bulls. It was reported that bull with intensive feeding systems showed higher daily weight gain, final weight, hot carcass weight, dressing percentage, and fatness than those with extensive feeding. Longer days on feed gave the same pattern as compared to shorter time on feeding. A better feeding regime either better in quality or longer in time on feeding supplied more nutrients to the animal body. Hence, the nutrients are utilized for maintenance and mostly for formation of body tissues including muscles (meat), bone and fat that were accumulated in the body during time on feeding/fattening.

\subsection{Proportion of carcass components}

Carcass is basically composed of edible and economically important part (meat) and non-edible or less economically important (bone and fat). Hence, proportion of meat, bone, fat, and especially meat : bone ratio are as important measures for carcass.

Good carcass must have higher proportion of meat or meat/bone ratio and lower proportion of fat and bone. In terms of carcass composition, meat: bone ratio is an indicator of muscularity (Mclntery, 2004). Data of proportion of meat, bone, fat, and meat : bone ratio of carcass of crossbred Brahman steers and heifers as affected by different period of fattening are presented in Table 2 .

Table 2. Proportion of carcass components (meat, bone, fat, and meat/bone ratio) of crossbred Brahman steers and heifers asaffected by different period of fattening

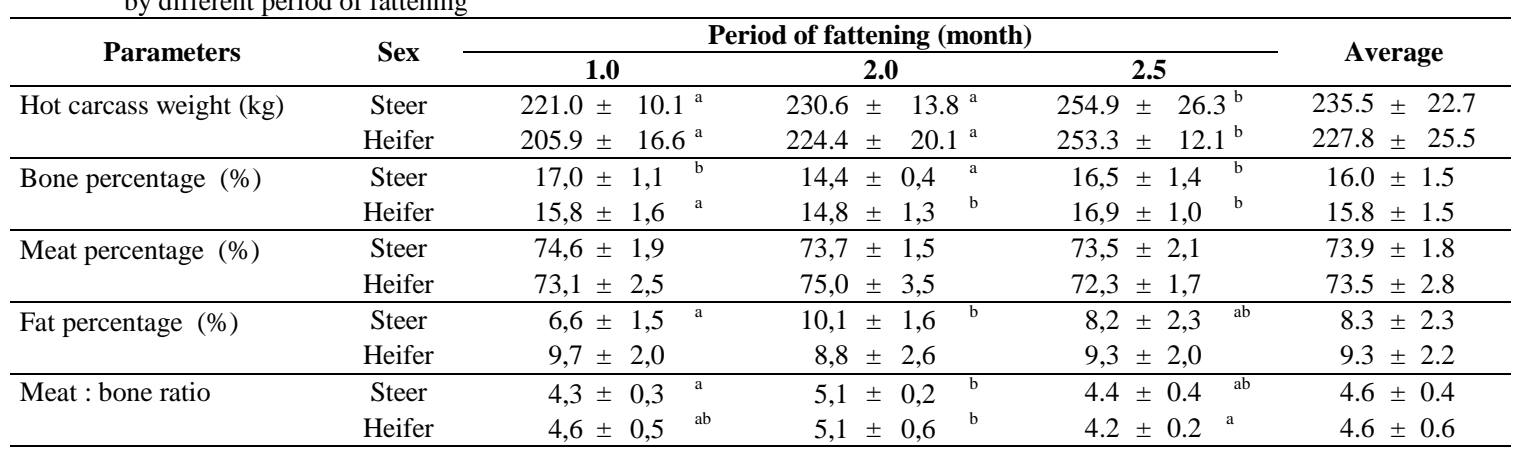

a, b) Values on the same row under the period of fattening column with different superscript are significantly different $(\mathrm{P}<0.05)$ 
Aberle et al (2001) reported that beef production can be evaluated bade on carcass component, the proportions of muscle, fat and bone. Phillip (2010) percentage of bone in carcass ranged from 13-16\%, muscle 54-68\%, and fat $13-31 \%$. Those values were much influenced by several factors, including genetics. In addition, bone percentage of carcass of Bos indicus breeds was reported by Orellana et al. (2009) in Criolo breed 23.9\%, Braford breed $20.4 \%$, Nellore breed 16.6\%, Nellore and European crossbreeds 15.2\%. Maggioni et al. (2010) found that crossbreeding reduced the percentage of bone and increased the percentage of muscle and fat. Mclntyre (2004) reported that meat carcass percentage ranged from 40-70\%. As compared to the above reports, data in Table 2 showed that carcass meat percentage of crossbred Brahman steers and heifers as affected by different period of fattening in this experiment was on high rank (72.3-75.0\%), while bone and fat percentage was on lower rank (14.4-17.0\% and 6.6-10.1\%, respectively).

Although there was significantly difference $(\mathrm{P}<0,05)$ of slaughter weight of steers and heifer as shown in Table 1, sex factor did not affect significantly some carcass characteristics including bone, meat, and fat weight or percentage as well as meat : bone ratio (Table 2). Steers and heifers showed not significantly different carcass meat and bone percentage as well as meat: bone ratio, but heifers showed slightly higher carcass fat percentage than steers. The same conditions were also reported by Reinhardt et al (2009). Garrett and Hinman (1971) reported that heifer carcass had greater fat content at common yield and quality grades.

Based on days on the feedlot or length of fattening period, carcass bone percentage showed highly significant difference $(\mathrm{P}<0.01)$ among the treatment. The lowest bone percentage was shown by steers and heifers fattened for 2 months period, $14.4 \%$ for steer and $14.8 \%$ for heifer and the highest bone percentage was $17.0 \%$ for steers and $16.9 \%$ for heifer after fattened for 2.5 months (Table 2).

Carcass meat percentage was not significantly different and tended to be relatively constant in all fattening period. However, steers showed the highest meat percentage $(74.6 \%)$ on one month fattening period and tended to decrease with longer fattening period. On the other hand, heifers showed the highest meat percentage $(75.0 \%)$ on two months fattening period. This different pattern of meat percentage in relation to fattening period indicated that steers needed shorter fattening period to reach highest meat percentage than heifers.

Carcass fat percentage of steers was significantly different $(\mathrm{P}<0.01)$ among fattening periods. The highest fat percentage of steers $(10.1 \%)$ was achieved after two months fattening period and the lowest one $(6.6 \%)$ was after one month fattening period. The carcass fat percentage of heifers was relatively constant and was not affected by fattening period. The highest carcass fat percentage of heifers $(9.7 \%)$ was achieved after one month fattening period. Aberle et al. (2001) reported that percentage of fat will increase as the growth occurs.

Meat : bone ratio was significantly affected $(\mathrm{P}<0.01)$ by fattening period both in steers and heifers. The highest meat : bone ratio was achieved on two months fattening period, i.e. 5.1\%, both in steers and heifers. The value was slightly higher than those reported by Mclntery (2004) and Bartoň et al. (2006). Average meat : bone ratio was $4.0 \%$ and ranged from 3.5 to 5.0\% (Mclntery, 2004). Barton̆ et al. (2006) reported that meat : bone ratio of Charolais, Aberdeen Angus, Hereford, and Simmental bulls was 4.56, 4.77, 4.86, and 4.90\%, respectivelly. However Mclntery (2004) stated that correlation of muscle weight and bone weight in carcass were relatively stable during fattening period.

In general the fattening of steers tended to be more quickly achieved than in heifers which indicates that it is better that steers are fattened for a shorter time than the heifers. This is done so that a high percentage of fat is not achieved.

\subsection{Meat quality}

One of important property of carcass is physical quality of meat. Parameter of the quality includes meat color, fat color, and marbling fat. The physical quality of meat influence strongly consumer's preference to the meat because consumers use meat discoloration as an indicator of freshness and wholesomeness (Mancini and Hunt, 2005). Data of physical quality of meat of crossbred Brahman steers and heifers as affected by different period of fattening are presented on Table 3.

Table 3. Meat quality (meat color, fat color, and marbling fat) of Brahman crossbred steers and heifers as affected by different period of fattening

\begin{tabular}{|c|c|c|c|c|c|c|c|}
\hline \multirow{2}{*}{ Parameters } & \multirow{2}{*}{ Sex } & \multicolumn{4}{|c|}{ Period of fattening (month) } & & \multirow{2}{*}{ Average } \\
\hline & & 1.0 & 2.0 & & 2.5 & & \\
\hline \multirow[t]{2}{*}{ Meat color } & Steer & $5,0 \pm 1,4$ & $4,0 \pm 0,5$ & $\mathbf{a}$ & $6,5 \pm 0,5$ & $\mathbf{b}$ & $5,2 \pm 1,3$ \\
\hline & Heifer & $5,7 \pm 1,1$ & $4,7 \pm 0,6$ & $\mathbf{a}$ & $6,4 \pm 0,5$ & b & $5,6 \pm 1,0$ \\
\hline \multirow[t]{2}{*}{ Fat color } & Steer & $2,0 \pm 0,3$ & $2,7 \pm 0,4$ & b & $1,8 \pm 0,4$ & & $2,5 \pm 0,5$ \\
\hline & Heifer & $3,0 \pm 0,6$ & $2,2 \pm 0,6$ & $\mathbf{a}$ & $2,0 \pm 0,3$ & a & $2,4 \pm 0,6$ \\
\hline \multirow[t]{2}{*}{ Marbling fat } & Steer & $2,1 \pm 0,4$ & $2,9 \pm 0,7$ & & $2,3 \pm 0,5$ & & $2,4 \pm 0,6$ \\
\hline & Heifer & $2,8 \pm 0,6$ & $2,6 \pm 0,6$ & & $2,7 \pm 0,4$ & & $2,7 \pm 0,5$ \\
\hline
\end{tabular}


a, b) Values on the same row under the period of fattening column with different superscript are significantly different $(\mathrm{P}<0.05)$

Meat color, fat color and marbling were not influenced by sex. The crossbred Brahman presented scores for meat color of 5.2 for steers and 5.64 for heifers. The dark red color in the crossbred Brahman presented a better meat quality for heifers than steers. Fat color score was 2.5 for steers and 2.5 for heifers, so fat color was white to slightly yellow as desired by consumer.

Marbling is a characteristic that affect the palatability and tenderness. The scores were 2.4 for steers and 2.7 for heifers which mean there was only a slight different in average amount of marbling. However the Indonesian meat market caters mostly for meatballs and other traditional foods, so marbling is less required.

In general, steer tends to produce higher carcass characteristics than the heifer (Table 1). Sex affects tissue growth and carcass composition in which heifer stops the feedlot phase at lower weight than steer.

Based on the days on feed, the meat color and marbling were not affected by the feedlot period, but the fat color was whiter after 1 month than 2 or more and white fat color is desired by consumers. Fat color is influenced by the feed primarily forage feed. Giving a higher percentage of forage will give a yellowish color on the carcass because of the beta carotene in the forage. However, feeding with high concentrate will provide lighter white colour of fat (Lawrie, 1998).

Based on the results, it can be concluded that:

\section{Conclusions}

1. The highest carcass percentage of the steers and heifers was reached after 2.5 months in the feedlot $(56.6 \%$ and $56.3 \%$ respectively).

2. Meat percentage (74.6\%) was highest in steers after 1 month and in the heifers (75.0\%) after 2 months fattening period.

3. The lowest percentage of bone in the steers and heifers was after 2 months fattening period $(14.4 \%$ and $14.8 \%$ respectively) while the percentage of fat of heifers was higher $(9.3 \%)$ than the steers $(8.2 \%)$ after 2.5 months fattening period in the feedlot.

4. The percentage of bone varied, while the percentage of meat (muscle percentage) was a relatively constant. The fat percentage increased due to the increased in the length of the days on feed.

5. The color and marbling score met the conditions of consumer tastes of Indonesian market.

\section{Acknowledgments}

The authors gratefully acknowledge to Mr. Tumiyana CEO of Widodo Makmur Perkasa Company for the facility support.

\section{References}

[1] Aberle, DE, J.C. Forrest, D.E. Gerrard, and E.W. Mills. 2001. Principles of Meat Science. Fourth Edition. W.H. Freeman and Company. San Francisco, United States of America.

[2] Bartoň L., D. Řehák, V. Teslík, D. Bureš, and R. Zahrádková. 2006. Effect of breed on growth performance and carcass composition of Aberdeen Angus, Charolais, Hereford and Simmental bulls. Czech J. Anim. Sci., 51, 2006 (2): 47-53.

[3] Behrends, S.M., R.K. Miller., F.M. Rouquette, Jr., R.D. Randel., B.G. Warrington., T.D.A. Forbes., T.H. Welsh., Lippke;, J.M. Behrends., G.E. Cartens and J.W. Holloway. 2009. Relationship of Temperament, Growth, Carcass Characteristics and Tenderness in Beef Steer..J. Meat Sci 81: 433-438.

[4] Chambaz, A., M.R.L. Scheeder., M. Kreuzer and P.A. Dufey. 2003. Meat Quality of Angus, Simmental, Charolais and Limousin Steers Compared at the Same Intramuscular Fat Content. J. Meat Sc. 63: 491-500.

[5] Choat, W. T., J. A. Paterson, B. M. Rainey, M. C. King, G. C. Smith, K. E. Belk and R. J. Lipsey. 2006. The effects of cattle sex on carcass characteristics and longissimus muscle palatability. J. Anim. Sci. 2006, 84:1820-1826.

[6] Cuvelier, C., A. Cliquart., J.F. Hocquette., J.F. Cabaraux., I. Dufrasne, L. L. Istasse and J.L. Hornick. 2006. Comparison of Composition and Quality Traits of Meat from Young Finishing Bulls from Belgian Blue, Limousin and Aberdeen Angus Breeds. J. Meat Sc 74: 522-531

[7] Drake. D.J. 2010. Understanding and Improving Beef Cattle Carcass Quality. Division of Agricultural and Natural Resources. University of California. http://anrcatalog.ucdavis.edu.

[8] Garrett, W. N., and N. Hinman. 1971. Fat content of trimmed beef muscles as influenced by quality grade, yield grade, marbling score and sex. J. Anim. Sci. 33:948-957.

[9] Hafid, H. 2004. Accuracy Using Carcass Weight and Fat Thickness ribs to 12 for Predicting Meat and Fat Content of Beef Carcasses in the ACC and BX. Agriplus Scientific Magazine 14 (03).

[10] Indonesian National Standart 3932. 2008. Carcass and Beef Quality. National Standardization Agency.ICS 67.120.10. INS 3932. 2008.

[11] Lambe, N.R., Ross, D.W., Navajas, E.A., Hyslop, J.J., Prieto, N., Craigie, C., Bunger, L., Simm, G and R. Roehe. 2010. The prediction of Carcass Composition and Tissue Distribution in Beef Cattle Using Ultrasound Scanning at the Start and/or end of the Finishing Period. Livestock Science:131:193-202.

[12] Lawrence, T.E., R.L. Farrow., B.L. Zollinger and K.S. Spivey. 2008. Technical note: The United States Departement of Agricultural Beef Yield Grade. J.Anim.Sci:86: 1434-1438.

[13] Lawrie, R.A. 1998. Meat Science. Taylor and Francis, Seri Woodhead Pubblishing Series in Food Science and Teknology. Cambridge. 
[14 Maggioni, D., J.A. Marques., P.P. Rotta and Perroto, D. 2010. Animal Performance and Meat Quality of Crossbred Young Bull Meat.Sci: 127:176-182.

[15] Mancini, R.A. and M.C. Hunt. 2005. Current research in meat color. Review. Meat Science 71 (2005): 100-121.

[16] Mandell, I. B., Gullett, E. A., Wilton, J. W., Allen, O. B., \& Kemp, R. A. (1998). Effects of breed and dietary energy content within breed on growth performance, carcass and chemical composition and beef quality in Hereford and Simmental steers. Canadian Journal Animal Science, 78, 533-541.

[17] McKlerrnan. B. 2007. Muscle Scoring Beef Cattle. NSW Departement of Primary Industries. State of New South Wales.

[18] Mclntyre, B. 2004. Yield of Saleable Meat in Beef Cattle. Farmnote. Departement of Agriculture. Government of Western Australia. State of Western Australia. No. 26.

[19] Orellana, C., F. Pena., A. Gracia., J. Perea., J. Martos., V. Domenech and R. Acero. 2009. Carcass Charcteristics, Fatty Acid Composition, and Meat Quality of Criollo Argentino and Braford Steer Raised on Forage in a Semi-Tropical Region of Argentina. Meat.Sci: 81: 57-64.

[20] Pietersen, T., Bruwer, GG., Naude, R.T and Vosloo. 1992. Secondary Sexual Development (masculinity) of Bovine Males: 1. Influence on Carcass Composition, Cutability, Economic Value and Certain Muscles. Meat.Sci. 31:4: 435-50.

[21] Phillips, C.J.C. 2010. Principles of Cattle production, 2 nd edition. Cambridge University Press. Cambridge. p.26-49.

[22] Reinhardt, C. D., W. D. Busby and L. R. Corah. 2009. Relationship of various incoming cattle traits with feedlot performance and carcass. J. Anim. Sci. 2009, 87:3030-3042.

[23] Sami, A.S., C. Augustini, F.J. Schwarz. 1998. Effects of feeding intensity and time on feed on performance, carcass characteristics and meat quality of Simmental bulls. Meat Science 67 (2004) 195-201.

[24] Smith, T., J.D. Domingue., J.C. Paschal., D.E. Tranke., T.D. Bidner and D. Whipple. 2007. Genetic Parameter for Growth and Cracss Traits of Brahman Steer. J. Anim.Sci: 85: 1377-1384.

[25] Soeparno. 2009. Meat and Technology Science. Gadjah Mada University Press, Yogyakarta. 